\title{
Growth patterns in R\&D partnerships: an exploratory statistical study
}

Citation for published version (APA):

Hagedoorn, J., \& van Kranenburg, H. L. (2003). Growth patterns in R\&D partnerships: an exploratory statistical study. International Journal of Industrial Organization, 21, 517-531. https://doi.org/10.1016/S0167-7187(02)00126-1

Document status and date:

Published: 01/01/2003

DOI:

10.1016/S0167-7187(02)00126-1

Document Version:

Publisher's PDF, also known as Version of record

\section{Please check the document version of this publication:}

- A submitted manuscript is the version of the article upon submission and before peer-review. There can be important differences between the submitted version and the official published version of record.

People interested in the research are advised to contact the author for the final version of the publication, or visit the DOI to the publisher's website.

- The final author version and the galley proof are versions of the publication after peer review.

- The final published version features the final layout of the paper including the volume, issue and page numbers.

Link to publication

\footnotetext{
General rights rights.

- You may freely distribute the URL identifying the publication in the public portal. please follow below link for the End User Agreement:

www.umlib.nl/taverne-license

Take down policy

If you believe that this document breaches copyright please contact us at:

repository@maastrichtuniversity.nl

providing details and we will investigate your claim.
}

Copyright and moral rights for the publications made accessible in the public portal are retained by the authors and/or other copyright owners and it is a condition of accessing publications that users recognise and abide by the legal requirements associated with these

- Users may download and print one copy of any publication from the public portal for the purpose of private study or research.

- You may not further distribute the material or use it for any profit-making activity or commercial gain

If the publication is distributed under the terms of Article $25 \mathrm{fa}$ of the Dutch Copyright Act, indicated by the "Taverne" license above, 


\title{
Growth patterns in R\&D partnerships: an exploratory statistical study
}

\author{
John Hagedoorn*, Hans van Kranenburg \\ MERIT, Faculty of Economics and Business Administration, Maastricht University, P.O. Box 616, \\ 6200 MD Maastricht, The Netherlands
}

Received 6 November 2001; received in revised form 24 May 2002; accepted 3 October 2002

\begin{abstract}
This paper offers the first statistical analysis of the long-term movement in inter-firm partnerships during the period 1960-1998. Our analysis indicates a growth pattern in R\&D partnering that is largely of a non-stationary nature, caused by fluctuations during the last 10 years of this time series. The further analysis of specific groups of these R\&D partnerships reveals that the patterns for so-called high-tech sectors, for the leading industrial nations and for the contractual R\&D partnerships follow the overall movement of these partnerships. (C) 2002 Elsevier Science B.V. All rights reserved.
\end{abstract}

JEL classification: L19

Keywords: R\&D partnerships; Trends

\section{Introduction}

An interesting aspect of the industrial organization literature from the 1980s and early 1990 s is that this period appears to have generated a relatively large number of studies on the movement of mergers and acquisitions (M\&As) (see e.g. Clark et

\footnotetext{
*Corresponding author. Tel.: +31-43-388-3823; fax: +31-43-388-4893.

E-mail addresses: j.hagedoorn@mw.unimaas.nl (J. Hagedoorn), h.vankranenburg@mw.unimaas.nl (H. van Kranenburg). 
al., 1988; Golbe and White, 1988, 1993; Shugart and Tollison, 1984). This academic interest in M\&As did not only coincide with the actual merger wave from the 1980s, the combination of the availability of extensive time series on M\&As in the USA and the emergence of advanced, econometric time series analysis must have been instrumental in increasing the number of these studies.

In more recent years, we notice that other modes of company governance, such as joint ventures and a wide range of inter-firm alliances, also increasingly attract academic attention that seems to parallel a growth in different forms of intercompany relationships (see e.g. Hagedoorn, 1996; Mytelka, 1991; Osborn and Hagedoorn, 1997; Vonortas, 1997). We would like to emphasize, however, that the expansion of research on joint ventures and alliances has, to the best of our knowledge, not led to even one single contribution that studies the long-term trends and patterns in these phenomena. Only a few studies, e.g. Gomes-Casseres (1988), Hagedoorn (1996) and Vonortas (1997), appear to hint at the possibility that alliances and joint ventures might demonstrate long-term trends comparable to M\&As.

A major reason for this omission is probably that the time series and databases available to study joint ventures and alliances appear to be extremely limited, both in terms of the actual number of databases and the time-horizon for most of these databases. The objective of our current contribution is to make a first attempt in filling this gap in the literature by means of an exploratory study that analyses the movement of inter-firm partnerships during a period of nearly forty years. This still relatively short time series, compared to the over a century-long time series used in many M\&A studies, implies that our econometric models have to remain quite basic. Moreover, the fact that we are dealing with unknown 'territory' suggests that it is wise to take this step-by-step. Therefore, this study is the very first step in an attempt to provide evidence concerning the statistical properties of a time series of $R \& D$ partnerships that may be susceptible to systematic interpretation. In that context, we will provide some guidance to future economic modeling of R\&D partnering activities.

Similar to the basic idea behind the previous studies on M\&As, we think it is important to first analyze the growth pattern in R\&D partnerships itself. Casual empiricism and some common characterization of changes in the number of inter-firm partnerships, as found in some databases, seem to support the idea that inter-firm partnerships might occur in a somewhat cyclical movement. Therefore, it is useful to test this formally in order to assure whether these appearances are empirically correct or not. A formal characterization of the growth pattern in partnerships may also be useful for an understanding of the limits of a prediction of future partnering activities as part of a broader economic growth pattern. Furthermore, a better understanding of the trend in inter-firm partnering could encourage the development of a wider set of hypotheses about the behavioural causes of this expected growth. In other words, once this basic understanding is 
established, future studies can develop a range of additional models that provide a further economic understanding of the growth pattern in R\&D partnerships. In our contribution we also discuss some important elements that we think might have to be incorporated in these future studies.

The starting point for our current analysis is the extension of previous studies on M\&As by Clark et al. (1988) and Shugart and Tollison (1984). These studies applied some basic models that we adapt to the analysis of inter-firm R\&D partnerships established during the period 1960-1998. This movement in total R\&D partnership activity and some sub-populations, which will be examined further in the following sections, is pictured in Fig. 1.

In the following analysis of the trend in inter-firm partnering activity, we will explicitly consider both deterministic and stochastic trends, that refer to two major approaches in time series analysis that have also played an important role in the study of M\&As. The models related to these different approaches will be introduced in the section below. This is followed by some background information on the data and the database that we analyze in this paper. The next section discusses the empirical results and the interpretation of the findings from the various models. The final section presents the conclusions from our exploratory study and it discusses some important elements to be considered for future economic modeling.

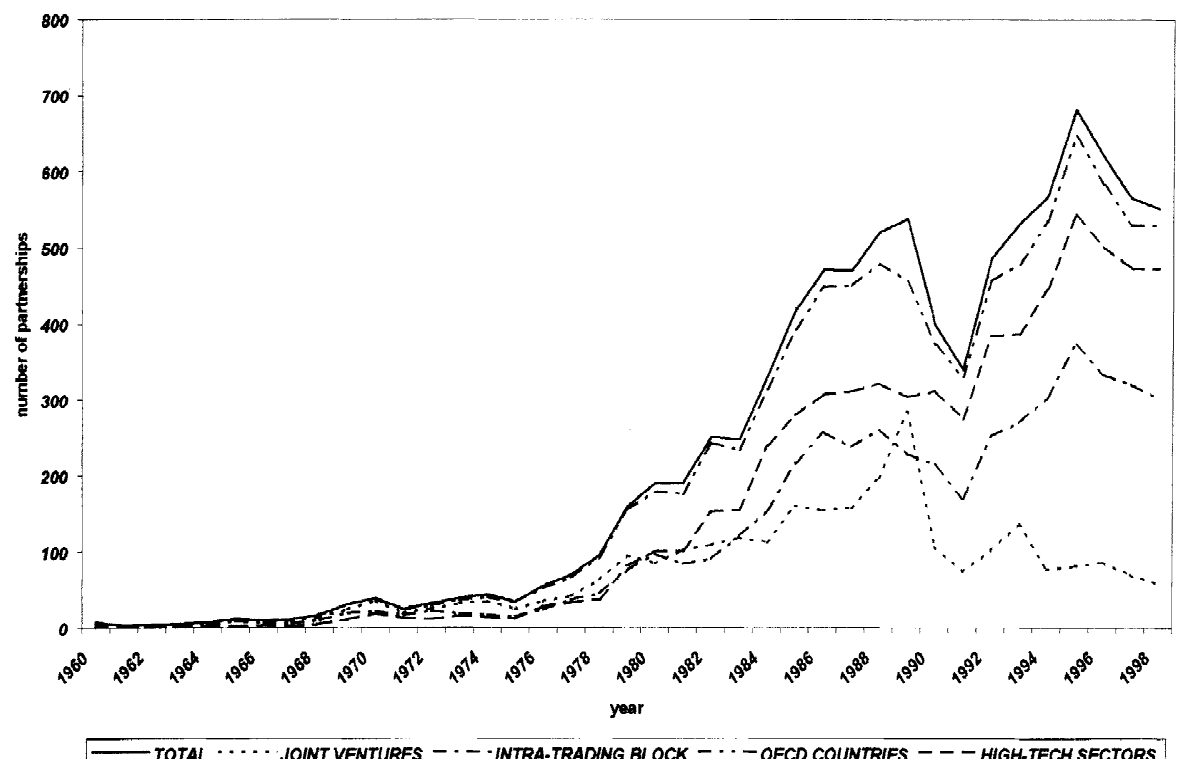

Fig. 1. The growth of newly established R\&D partnerships (1960-1998). 


\section{Methodology}

The classic literature on time series (Nelson and Plosser, 1982) demonstrates that many time series involve higher order of autoregression, which implies that, unless higher order terms are included, standard regression models could generate biased estimates. It is also possible that the actual time series may have both deterministic and stochastic trend elements. For the analysis of trends in R\&D partnerships such combined models with higher order terms can be rewritten as:

$$
P_{t}=\alpha+\phi_{1} P_{t-1}+\sum_{J=2}^{K} \phi_{j}\left(P_{t-j+1}-P_{t-j}\right)+\beta t+\varepsilon_{t}
$$

where $t$ represents linear time trend, $\alpha$ and $\beta$ are fixed parameters, $P_{t}$ is the actual number of $\mathrm{R} \& \mathrm{D}$ partnerships at a given time, where $\phi_{1}$ is the first-order autoregressive parameter describing the effect of a unit of change in $P_{t-1}$ on the dependent variable and where $\phi_{j}$ indicates the coefficients of higher order autoregression, and $\varepsilon_{t}$ denotes the error term. Given the nature of the data, we can also analyze the time series as moving at a constant rate. Consequently, the functional form of Eq. (1) can be specified as:

$$
\log P_{t}=\alpha+\phi_{1} \log P_{t-1}+\sum_{J=2}^{K}\left(\log P_{t-j+1}-\log P_{t-j}\right)+\beta t+\varepsilon_{t}
$$

where $\log P_{t}$ is the logarithm of $P_{t}$ and $\beta$, a constant growth rate in $P_{t}$.

Eqs. (1) and (2) represent the general form of a group of models with a linear trend that are combined with autoregression models. If the restriction $\phi_{1}=\phi_{j}=0$ is imposed, then the general form equations are in fact identical to simple linear trend models that represent a time series following only a deterministic pattern.

Another common model in the literature is the simple first-order autoregressive trend model that can be derived if we assume that $\beta=0$ and $\phi_{j}=0$. Contrary to the linear trend model, the autoregressive trend model does not consider the trend factor $(t)$ as an independent element on the right hand side of the equation. In this model the trend factor $(t)$ is inherently embodied in the dynamic process of the difference equation form. There are some comments to be made regarding this autoregressive model. First, stationarity requires that $\left|\phi_{1}\right|<1$. Second, if $\alpha$ is constrained to zero, then the value of $\phi_{1}$ is the rate of change in $P_{t}$ in (1) or the rate of growth of $\log P_{t}$ in (2). Finally, a random walk process follows if the restriction $\phi_{1}=1$ is imposed and the error terms are postulated as being serially uncorrelated. Then, the changes in $P_{t}$ are created by a purely random white-noise series. As the random walk is an integrated model, depending on the sequence of these random shocks, the realized series can move upward or downward from its initial value.

As such the specifications of (1) and (2) merge a deterministic trend analysis with a stochastic trend approach that enables us to catch both the secular trend and 
the extrapolative effect on the movement of the number of inter-firm partnerships. The determination of the optimal order of the lagged differenced terms remains an empirical issue.

\section{Data}

Unfortunately there are only a few databases on inter-firm partnerships and other hybrid forms of company governance. Most of these databases have been updated for a limited number of years or they have only been in existence for a short period of time (Hagedoorn et al., 2000). Consequently, due to the lack of data, none of these databases can be used for the current analysis. The data on R\&D partnerships that are analyzed in the following sections is taken from the only database on this topic that covers an extended period of time, i.e. the MERIT-CATI databank.

The MERIT-CATI data bank, maintained by a research team at the University of Maastricht, is a relational database that contains separate data files that can be linked to each other and that provides both disaggregated and combined information from several files. So far information on thousands of technologyrelated inter-firm partnerships has been collected for the period 1960-1998. Systematic collection of inter-firm partnerships started in 1986. Many sources from earlier years were consulted to establish a retrospective view. In order to collect information on inter-firm alliances various sources were consulted: newspaper and journal articles, books dealing with the subject, and in particular specialized journals that report on business events. Company annual reports, the Financial Times Industrial Companies Yearbooks and Dunn and Bradstreet's 'Who Owns Whom' provide information about dissolved equity ventures and investments, as well as new ventures that were not registered when surveying alliances. Additional information on this database can be obtained from the authors.

This method of information gathering that one can refer to as 'literature-based alliance counting' has its drawbacks and limitations due to the lack of publicity for certain arrangements and the low profile of certain groups of companies and some fields of technology. Despite these shortcomings, which are largely unsolvable, even in a situation of extensive and large-scale data-collection, this database is able to produce a clear picture of the joint efforts of many companies. In that context it is interesting to note that some of the other databases, that either concentrate on a specific industry or that are limited in terms of their time-span, appear to generate similar growth patterns. For instance, Bioscan reveals that in the biotechnology industry one notices a similar trend for the second half of the 1980s and the first half of the 1990s. Data on a wide variety of cooperative agreements generated by Securities Data also show a growth and down turn during the years 1985-1993 and a renewed growth in more recent years. This similarity in data trends from other databases does suggest that the potential errors in our 
Table 1

Distribution of different categories of R\&D partnerships, 1960-1998 with sub-periods

\begin{tabular}{|c|c|c|c|c|c|}
\hline \multirow[t]{2}{*}{ Sub-period } & \multicolumn{5}{|c|}{ Form of $R \& D$ partnership } \\
\hline & $\begin{array}{l}\text { Total of newly } \\
\text { established R\&D } \\
\text { partnerships }\end{array}$ & $\begin{array}{l}\text { Newly established } \\
R \& D \text { joint } \\
\text { ventures }\end{array}$ & $\begin{array}{l}\text { Newly established } \\
\text { R\&D partnerships } \\
\text { within trading } \\
\text { blocks }\end{array}$ & $\begin{array}{l}\text { Newly established } \\
\text { R\&D partnerships } \\
\text { within OECD } \\
\text { countries }\end{array}$ & $\begin{array}{l}\text { Newly established } \\
\text { R\&D partnerships } \\
\text { in high-tech } \\
\text { sectors }\end{array}$ \\
\hline 1960-1969 & 107 & 90 & 65 & 104 & 31 \\
\hline 1970-1979 & 592 & 407 & 294 & 569 & 264 \\
\hline 1980-1989 & 3627 & 1482 & 1747 & 3375 & 2271 \\
\hline 1990-1998 & 4743 & 791 & 2536 & 4464 & 3795 \\
\hline \multicolumn{6}{|c|}{$\begin{array}{l}\text { Total of newly } \\
\text { established R\&D }\end{array}$} \\
\hline partnerships & 9096 & 2770 & 4642 & 8512 & 6361 \\
\hline
\end{tabular}


data are probably limited and they do not seem to bias the results obtained from our analysis.

The CATI data bank contains information on each agreement and some information on companies participating in these agreements. The first entity is the inter-firm cooperative agreement. Cooperative agreements are defined as common interests between independent (industrial) partners that are not connected through (majority) ownership. In the CATI database only those inter-firm agreements are being collected that contain some arrangements for transferring technology or performing joint R\&D. Joint research pacts and second-sourcing are clear-cut examples. Information is also collected on joint ventures in which new technology is received from at least one of the partners, or joint ventures having some $R \& D$ program. Mere production or marketing joint ventures are excluded. In other words, this material is primarily related to R\&D collaboration and technology cooperation, i.e. those agreements for which a combined innovative activity or an exchange of technology is at least part of the agreement. The database has an international coverage, although by the nature of its content most of the registered agreements are found in the OECD countries and a small number of newly industrializing countries.

For our current analysis we will use data on $R \& D$ partnerships, i.e. alliances of which the main objective is to jointly perform $R \& D$, because this is not only the largest group of alliances within the database, it is also the most homogeneous category in terms of its main objectives. Apart from general counts, we also consider differences between joint ventures and contractual agreements, differences between intra-trading block and extra-trading block alliances, OECD versus non-OECD participation, and high-tech and non-high-tech R\&D partnerships.

As we mostly have only information on the year that an R\&D partnership is established and not on the year that a partnership is dissolved, our time series analysis is restricted to count data on annually, newly established partnerships. Table 1 presents the summary statistics of the R\&D partnership variable for the full sample as well as the sub-samples. It exhibits a total of 9096 newly established R\&D partnerships between 1960 and 1998. Of this total of newly founded R\&D partnerships only 2270 were joint ventures and the majority of these partnerships occurred between companies from OECD countries and high-tech industries. The table also shows that about $51 \%$ of the R\&D partnerships are made between companies within particular trading blocks, such as North America, the European Union and Asia. It is interesting to notice that the total number of joint ventures declined during the last sub-period, while the number of other forms of $R \& D$ partnerships increased.

\section{Empirical results}

The linear trend models were estimated using the data on R\&D partnerships for the period 1960-1998, see also Fig. 1. The results are presented in Table 2. Most 
Table 2

Regression estimates of the trend factor in R\&D partnering activity (1960-1998)

\begin{tabular}{|c|c|c|c|c|c|c|c|c|c|}
\hline \multirow[t]{2}{*}{ Equation } & \multirow{2}{*}{$\begin{array}{l}\text { Dependent } \\
\text { variables }\end{array}$} & \multicolumn{8}{|c|}{ Independent variables } \\
\hline & & $C$ & $t$ & $P_{t-1}$ & $\left(P_{t-1}-P_{t-2}\right)$ & $\log P_{t-1}$ & $\log P_{t-1}-\log P_{t-2}$ & Adj. $R^{2}$ & D.W. \\
\hline (1) & $P_{t}$ & $\begin{array}{r}-145.267^{\mathrm{b}} \\
(-5.378)\end{array}$ & $\begin{array}{l}18.890^{\mathrm{b}} \\
(16.051)\end{array}$ & & & & & 0.871 & 0.36 \\
\hline (2) & $\log P_{t}$ & $\begin{array}{r}1.572^{\mathrm{b}} \\
(10.488)\end{array}$ & $\begin{array}{r}0.146^{\mathrm{b}} \\
(22.344)\end{array}$ & & & & & 0.929 & 0.39 \\
\hline (3) & $P_{t}$ & $\begin{array}{l}16.123 \\
(1.454)\end{array}$ & & $\begin{array}{c}0.991^{\mathrm{b}} \\
(27.980) \\
{[0.278]}\end{array}$ & & & & 0.954 & 1.66 \\
\hline (4) & $\log P_{t}$ & $\begin{array}{c}0.241 \\
(1.865)\end{array}$ & & & & $\begin{array}{r}0.972^{\mathrm{b}} \\
(35.709) \\
{[1.037]}\end{array}$ & & 0.972 & 1.65 \\
\hline (5) & $P_{t}$ & $\begin{array}{r}-42.001 \\
(1.667)\end{array}$ & $\begin{array}{c}5.430^{\mathrm{a}} \\
(2.600)\end{array}$ & $\begin{array}{c}0.735^{\mathrm{b}} \\
(7.299) \\
{[2.624]}\end{array}$ & $\begin{array}{c}0.256 \\
(1.578)\end{array}$ & & & 0.958 & 1.92 \\
\hline (6) & $\log P_{t}$ & $\begin{array}{c}0.452^{\mathrm{b}} \\
(3.078)\end{array}$ & $\begin{array}{c}0.011 \\
(0.705)\end{array}$ & & & $\begin{array}{c}0.879^{\mathrm{b}} \\
(9.040) \\
{[1.247]}\end{array}$ & $\begin{array}{c}0.061 \\
(0.415)\end{array}$ & 0.980 & 1.98 \\
\hline
\end{tabular}


Table 3

Estimates of autoregressions for R\&D partnering activity (1960-1998)

\begin{tabular}{|c|c|c|c|c|c|c|c|c|c|c|c|c|}
\hline \multirow[t]{2}{*}{ Equation } & \multirow{2}{*}{$\begin{array}{l}\text { Dependent } \\
\text { variables }\end{array}$} & \multicolumn{11}{|c|}{ Independent variables } \\
\hline & & $C$ & $P_{t-1}$ & $P_{t-2}$ & $\Delta P_{t-1}$ & $\Delta P_{t-2}$ & $\log P_{t-1}$ & $\log P_{t-2}$ & $\Delta \log P_{t-1}$ & $\Delta \log P_{t-2}$ & Adj. $R^{2}$ & D.W. \\
\hline (7) & $P_{t}$ & $\begin{array}{l}16.801 \\
(1.402)\end{array}$ & $\begin{array}{c}1.158^{\mathrm{b}} \\
(6.852)\end{array}$ & $\begin{array}{c}-0.178 \\
(1.035)\end{array}$ & & & & & & & 0.951 & 1.92 \\
\hline (8) & $\log P_{t}$ & $\begin{array}{c}0.383^{\mathrm{b}} \\
(3.530)\end{array}$ & & & & & $\begin{array}{c}0.962^{\mathrm{b}} \\
(7.231)\end{array}$ & $\begin{array}{c}-0.017 \\
(0.126)\end{array}$ & & & 0.980 & 2.02 \\
\hline (9) & $\Delta P_{t}$ & $\begin{array}{l}12.420 \\
(1.438)\end{array}$ & & & $\begin{array}{c}0.160 \\
(0.959)\end{array}$ & & & & & & -0.002 & 1.91 \\
\hline (10) & $\Delta \log P_{t}$ & $\begin{array}{c}0.139^{\mathrm{b}} \\
(3.226)\end{array}$ & & & & & & & $\begin{array}{c}0.0140 \\
(0.100)\end{array}$ & & -0.028 & 1.81 \\
\hline (11) & $\Delta P_{t}$ & $\begin{array}{l}17.022 \\
(1.883)\end{array}$ & & & $\begin{array}{c}0.198 \\
(1.182)\end{array}$ & $\begin{array}{c}-0.287 \\
(1.670)\end{array}$ & & & & & 0.046 & 1.89 \\
\hline (12) & $\Delta \log P_{t}$ & $\begin{array}{c}0.144^{\mathrm{b}} \\
(2.845)\end{array}$ & & & & & & & $\begin{array}{c}0.093 \\
(0.546)\end{array}$ & $\begin{array}{c}-0.164 \\
(1.158)\end{array}$ & -0.010 & 1.98 \\
\hline
\end{tabular}


of the estimations exhibit a rather deterministic trend that could play an important role in explaining the movement of R\&D partnerships.

For the models (1), (2) and (5), the time variable has the expected positive sign and it is significant at the 5 or $1 \%$ level, using a two-tailed test. This seems to confirm the basic hypothesis that R\&D partnering activities are positively correlated with the time trend. However, the Durbin-Watson statistics for (1) and (2) indicate that the time series of $R \& D$ partnerships is characterized by serial correlation. In other words, the simple linear trend model of (1) and (2) is inadequate to describe the data (Gujarati, 1992).

The results for models (3)-(6) show that R\&D partnering activity is highly correlated with the partnering activity in the previous year. The $t$-statistics of the coefficients for the various lagged dependent variables are all statistically significant at the $99 \%$ confidence level.

One of the results from Table 2 is that the growth in R\&D partnerships demonstrates a stochastic trend characteristics, see (5) and (6). ${ }^{1}$ However, under the random walk assumption, the statistical inference for models (3)-(6) based on the conventional $t$-statistics may be biased (Dickey and Fuller, 1979 and 1981). Therefore, an additional test is needed to see whether the coefficient of the lag variable is equal to one. The results (see Table 2, between square brackets) show that the existence of a unit root cannot be rejected in these models. The process has an infinitely long memory and the R\&D partnership activity can be modeled as a random walk, i.e. a stochastic trend.

For the longer lagged effect we estimated the autoregression model by including a second-order polynomial, see Table 3. Models (7) and (8) exhibit that the coefficients on the first order lag $\left(\phi_{1}\right)$ are positive. However, since the estimated value of $\phi_{1}$ in model (7) is greater than 1 , the R\&D partnering time series appears to be non-stationary. The second order lag $\left(\phi_{2}\right)$ is negative but not significant in (7) and (8). The empirical finding indicates that the exclusion of a higher order would not bias the coefficient estimates. These outcomes do not indicate that R\&D partnership movements follow a deterministic trend.

We also included some higher order lags (3-5 years) in the model. As none of these variables were found to be statistically significant, we do not report or further discuss the specifics of these findings.

To analyze the possibility of a stochastic process in the R\&D partnership series, the spurious element has to be removed from the trend factor. The autoregressions (9)-(12) can be estimated once the series had been differenced. The difference equations (9)-(12) in Table 3 demonstrate that the estimated coefficients for the first order lag $\left(\phi_{1}\right)$ and the second order lag $\left(\phi_{2}\right)$ in (11) and (12) are not statistically significant. The coefficients of the constant terms are, with the exception of (11), substantially lower than for (7) and (8). Moreover, the

\footnotetext{
${ }^{1}$ Similar results are found in some other studies on comparable socio-economic time series, see Clark et al. (1988), Nelson and Plosser (1982) and Shugart and Tollison (1984).
} 
Durban-Watson statistics indicate that there is no serial correlation problem in this part of the analysis. However, the values of the $R^{2}$ statistics decline dramatically which implies that it is only due to the spurious factor that a time series model with the deterministic trend generates a high $R^{2}$. These findings suggest that, given a general growth trend in $R \& D$ partnerships, the actual pattern could largely be of a stochastic nature.

So far this analysis has focused on time series of general counts of newly established R\&D partnerships. It is possible, however, that there are a number of particular characteristics of these $R \& D$ partnerships or different forms of $R \& D$ partnering that constitute different sub-populations that might be affected by specific historical patterns. ${ }^{2}$ The literature on inter-firm partnerships (see Hagedoorn, 1996; Mytelka, 1991; Osborn and Hagedoorn, 1997 for overviews) suggests that particular characteristics, in terms of industry-specificity, organizational traits and international distributions, play an important role in differentiating the overall population of partnerships into several sub-populations.

However, our further investigation of these sub-populations reveals that the pattern for nearly all of these sub-populations of R\&D partnerships turned out to be quite identical to the general pattern described in the above. For instance, a differentiation into R\&D partnerships established within the OECD countries or outside the OECD generates no additional insight. R\&D partnerships among companies from the OECD countries make up for about $95 \%$ of the population. Not surprisingly, the findings for the OECD countries are the same as those reported in the above. The numbers for other countries are too small for this sort of statistical analysis (see also Table 1).

The same applies to the differentiation of high-tech and non-high-tech R\&D partnerships (see Fig. 1). The vast majority of $R \& D$ partnerships are found in high-tech sectors, such as pharmaceuticals, electronics and information technology-based sectors and aviation and defense. The analysis of the time series of R\&D partnerships found in high-tech sectors generates the same results as for the general counts, whereas the analysis of newly established R\&D partnerships in other sectors is seriously flawed due to small numbers.

Given the fact that by far most of the R\&D partnerships are of a contractual nature (see Fig. 1), it is no surprise that the analysis of the time series of contractual R\&D partnerships generates similar results as for the general counts.

\footnotetext{
${ }^{2}$ An interesting question related to the overall growth pattern in R\&D partnerships refers to the downturn in newly established partnerships in the period 1989-1992. To the best of our knowledge there are no publications that offer a solid explanation for this decrease. Some popular press releases refer to the shortage of venture capital and the bankruptcy rate affecting the number of attractive small companies as partners in high-tech industries after the 1988 stock market 'crash'. However, our data (see Fig. 1) suggest that the decline in R\&D partnerships in high-tech industries is rather moderate compared to the decline in the overall population. Furthermore, as explained in the next section, this sudden change in the number of newly made partnerships could, based on the current statistical evidence, still be interpreted as a random fluctuation.
} 
The analysis of the low growth in newly established R\&D joint ventures did not bring any surprising results either. Finally, we considered some possible differences between the R\&D partnerships made between companies within particular trading blocks, such as North America, the European Union and Asia, and inter-trading block partnerships established between companies from these different trading blocks. This would indicate the degree to which international differences and 'distance' plays a role in the general growth pattern of $R \& D$ partnerships. Again, the results for the regression estimates of the trend factor and the estimates of the autoregressions were quite similar to those found for the overall counts.

\section{The stochastic nature of $R \& D$ partnering activity}

An important finding from this study is that $R \& D$ partnership movements exhibit evidence of stochastic characteristics. In that context it is interesting to examine the hypothesis that R\&D partnership activity can be modeled as a white noise process, i.e. the first differences in the series appear to be of a random walk nature with possible drift. The alternative model for the random walk model is the general autoregressive Eq. (2) with $\phi_{j}=0$ for all $j>1$. To examine whether the time series is adequately represented by Eq. (2), we employed the 'nested' likelihood ratio tests suggested by Dickey and Fuller (1981). The results from applying the Dickey-Fuller methodology to the logarithms of the annual number of newly established R\&D partnerships are summarized in Table 4.

On the basis of the calculated test statistics the null model evaluated against the alternative containing a deterministic trend (Eq. (2)) cannot be rejected. However, the likelihood ratio test shows that the hypothesis that the appropriate model is one of first-order autoregression with drift, $\left(\alpha, \phi_{1}\right) \neq(0,1)$, should be accepted. Overall, the available evidence suggests that the white noise model quite adequately fits the R\&D partnership series. The estimated drift coefficient of the white noise model indicates that the number of $R \& D$ partnerships grew annually

Table 4

Likelihood ratio tests for R\&D partnering activity (1960-1998)

\begin{tabular}{llll}
\hline Dickey and Fuller (1981) & Null model & Alternative model & Test statistics \\
\hline Logarithms & $\left(\alpha, \phi_{1}\right)=(0,1)$ & Eq. (2) with no & $\Phi_{1}=10.406^{\mathrm{b}}$ \\
& $\left(\alpha, \beta, \phi_{1}\right)=(0,0,1)$ & Eq. (2) & $\Phi_{2}=5.983^{\mathrm{a}}$ \\
& $\left(\alpha, \beta, \phi_{1}\right)=(\alpha, 0,1)$ & Eq. (2) & $\Phi_{3}=3.136$ \\
\hline
\end{tabular}

\footnotetext{
a Significant at the $5 \%$ level.

${ }^{\mathrm{b}}$ Significant at the $1 \%$ level.
} 
with at least $10 \%{ }^{3}$ Estimating this model for the R\&D partnership time series, we obtain $\log P_{t}=0.115+\log P_{t-1}$, with constant sample variances. The existence of the unit root could indicate a herd-behaviour like growth pattern. In other words, the remarkable growth in the number of newly established R\&D partnerships could be caused by the decision of companies to either continue establishing new partnerships with their existing partners or to ally with other companies.

\section{Implications and conclusions}

There is some evidence in the previous research on M\&As that these M\&As follow a short-term autoregressive trend (Clark et al., 1988) and some research even suggests a cyclical pattern in this overall growth trend (Golbe and White, 1993). The empirical conclusions from our research on a relatively short time series of 39 years of R\&D partnering, however, only indicates the systematic nature of the overall growth in the number of $R \& D$ partnerships in a nonstationary process. This non-stationary process could be caused by random fluctuations in this growth pattern, particularly during the last ten years of this time series. The current analysis certainly does not falsify the hypothesis that the growth pattern in R\&D partnering activities is largely of a random nature. In that sense our findings on R\&D partnerships are similar to the findings on trends in M\&As by Shugart and Tollison (1984).

Extrapolations based on autoregressive trend analysis, or many other time series analytical tools for that matter, are subject to the criticism that they only cover internal dynamics while ignoring external factors relevant for understanding causal relations as found in a structural model based on a positive theory. Given the exploratory nature of the current study and the elementary theory development in this area of research, we cannot apply such a structural model. The results for the additional analysis of the different sub-populations of R\&D partnerships indicate that some exogenous factors could be more important to include in future models. Therefore, apart from the basic need to collect longer time series, future research in this area will have to concentrate on a broad set of external factors that might be helpful in generating a better understanding of the specifics of the growth pattern in these inter-firm partnerships. An interesting approach could be found in investigating the underlying factors, such as R\&D expenditures and the number of firms in high-tech industries, that can explain the non-stationary growth trend of R\&D partnerships and their implications for the evolution of the number of partnerships (see e.g. Mancke, 1974; Jones, 1995). Structural models of growth could then encompass the time series evidence of R\&D partnering and these

\footnotetext{
${ }^{3}$ This result of a random walk with drift is also obtained for the sub-populations time series, with the exception of joint ventures where the pattern can be characterized as a random walk without drift.
} 
underlying factors. However, there are serious limitations to international data and many problems related to the comparability of different datasets for R\&D inputs, M\&As, number of companies and other economic indicators. Therefore, such an approach with an extended model should probably concentrate on one country instead of focusing on an international population of $R \& D$ partnerships.

Other topics for future research might be found in the combined time series analysis of partnerships and M\&As and the effect of market volatility on trends and patterns in inter-firm partnership formation. A comparison of trends in aggregate data on US M\&As during the period 1960-1998 already suggests that the growth pattern for M\&As is considerably different from the pattern found for R\&D partnerships (Gaughan, 1999).

Finally, we would like to emphasize that this paper is, to the best of our knowledge, the very first attempt to present an analysis of long-term trends in R\&D partnerships. These partnerships are widely discussed in the literature with reference to their economic impact, their growth in recent years, their organizational features, and their sectoral distribution. The current contribution is exploratory and its limitations are largely due to a lack of data. To some extent this is similar to the early contributions on M\&A trend analysis from the 1980s. Still these early contributions also provided useful insight for others to build on. In that sense, our paper ties into a broadening body of literatures on inter-firm partnering while paying attention to a set of questions that deal with some basic properties of the general growth pattern in these $R \& D$ partnerships.

\section{Acknowledgements}

The authors would like to thank Alok Chakrabarti, Denis de Crombrugghe, Stephen Martin, Franz Palm, Nick Vonortas and two anonymous referees for helpful comments on earlier drafts of this paper.

\section{References}

Clark, J.J., Chakrabarti, A.K., Chiang, T.C., 1988. Trends and stochastic movements in US merger activity. Quarterly Review of Economics and Business 28, 6-19.

Dickey, D.A., Fuller, W.A., 1979. Distribution of the estimators for autoregressive time series with a unit root. Journal of the American Statistical Association 74, 427-431.

\footnotetext{
${ }^{4} \mathrm{~A}$ technical, but rather important, problem that arises in the context of such new directions for research is that des-aggregated data on M\&As, R\&D expenditures, R\&D employment, numbers of companies, and other company-level indicators is found in databases owned by companies such as Thomson, Dunn and Bradstreet, etc. The combined costs for using these databases can, however, create a serious limitation to further research.
} 
Dickey, D.A., Fuller, W.A., 1981. Likelihood ration statistics for autoregressive time series with a unit root. Econometrica 49, 1057-1072.

Gaughan, P.A., 1999. Mergers, Acquisitions, And Corporate Restructurings. Wiley, New York.

Golbe, D.L., White, L.J., 1988. Mergers and acquisitions in the US economy: an aggregate and historical overview. In: Auerbach, A.J. (Ed.), Mergers and Acquisitions. University of Chicago Press, Chicago, pp. 25-47.

Golbe, D.L., White, L.J., 1993. Catch a wave: the time series behavior of mergers. Review of Economics and Statistics 75, 493-499.

Gomes-Casseres, B., 1988. Joint venture cycles: the evolution of ownership strategies of US MNEs, 1945-1975. In: Contractor, F.J., Lorange, P. (Eds.), Cooperative Strategies in International Business. Lexington Books, Lexington, pp. 111-128.

Gujarati, D., 1992. Essentials of Econometrics. McGraw-Hill, New York.

Hagedoorn, J., 1996. Trends and patterns in strategic technology partnering since the early seventies. Review of Industrial Organization 11, 601-616.

Hagedoorn, J., Link, A., Vonortas, N., 2000. Research partnerships. Research Policy 29, 567-586.

Jones, C.L., 1995. R\&D-based models of economic growth. Journal of Political Economy 103, $759-784$.

Mancke, R.B., 1974. Causes of interfirm profitability differences: a new interpretation of the evidence. Quarterly Journal of Economics 88, 181-193.

Mytelka, L.K. (Ed.), 1991. Strategic Partnerships and the World Economy. Pinter, London.

Nelson, C.R., Plosser, C.I., 1982. Trends and random walk in macro-economic time series: some evidence and implications. Journal of Monetary Economics 10, 185-217.

Osborn, R.N., Hagedoorn, J., 1997. The institutionalization and evolutionary dynamics of interorganizational alliances and networks. Academy of Management Journal 40, 261-279.

Shugart, W.F., Tollison, R.D., 1984. The random character of merger activity. Rand Journal of Economics 15, 500-509.

Vonortas, N.S., 1997. Cooperation in Research and Development. Kluwer, Boston. 